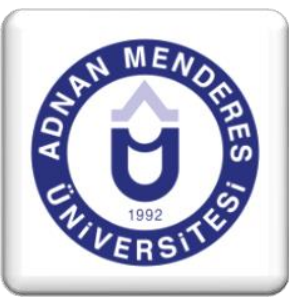

\title{
Gayrisafi Milli Mutluluğun Ekonomik Kalkınmadaki Rolü: Bhutan Krallığı Örneği ${ }^{1}$
}

\author{
Nursen VATANSEVER DEVIREN ${ }^{2}$, Onur YILDIZ ${ }^{3}$
}

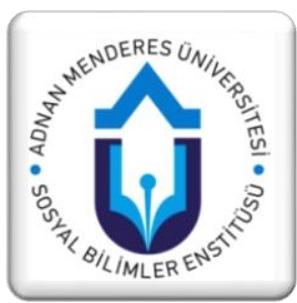

\section{ÖZET}

Ekonomik kalkınma, bir ülkedeki üretim ve gelir artışlarının yanı sıra niteliksel değişim sürecini içermektedir. Ekonomik kalkınma; ekonomik, sosyal, kültürel ve politik alanlarda yaşanan yapısal değişim süreci olarak tanımlanabilir. $\mathrm{Bu}$ süreçte insanların yaşam standartlarının iyileştirilmesi son derece önemlidir. İyileşen yaşam standartlarına bağlı olarak insanlar mutlu bireyler haline gelebilecektir. Bu bağlamda, ekonomik kalkınmayla ilişsilendirilen mutluluk ekonomisi, önemli bir konudur ve son yıllarda dikkat çekmektedir. Mutluluk ekonomisi, bireylerin mutluluğunu arttıran kamu politikalarının nasıl yapılacağı ile ilgilenmektedir. Mutluluk ekonomisi makroekonomik politikaların sonucu olarak ekonomik kalkınmanın bireysel refahı nasıl etkilediğini incelemektedir. Bu çerçevede gayrisafi milli mutluluk ilk defe 1972'de Bhutan Krallığı'nda gündeme gelmişsir. $\mathrm{Bu}$ çerçevede gayrisafi milli mutluluk kavramı, mutluluk ekonomisi literatüründe kendine önemli bir yer edinmiştir. Gayrisafi milli mutluluk; psikolojik iyi oluş, sağlık, zaman kullanımı, eğitim, kültürel çeşitlilik ve esneklik, iyi yönetişim, topluluğun canlılığı, ekolojik çeşitlilik ve esneklik ile yaşam standardı olmak üzere dokuz göstergeden oluşmaktadır.

Çalışma nitel bir araştırma olup ekonomik kalkınmada gayrisafi milli mutluluğun rolünü Bhutan Krallığı örneği çerçevesinde değerlendirmektedir. Çalışma, ikincil kaynaklara, raporlara ve gayrisafi milli mutluluğa ilişkin elde edilen verilere dayanmaktadır. Bu çalışmada gayrisafi milli mutluluğun ekonomik kalkınmadaki rolü, Bhutan Krallı̆̆ örneği çerçevesinde incelenmektedir.

Anahtar Kelimeler: Kalkınma, Ekonomik Kalkınma, Mutluluk, Gayrisafi Milli Mutluluk, Mutluluk Ekonomisi

\section{The Role of the Gross National Happiness in the Economic Development: The}

\section{Example of the Kingdom of Bhutan}

\section{ABSTRACT}

Economic development includes the process of qualitative change as well as increases in production and income in a country. Economic development can be defined as a process of change in the fields of economic, social, cultural and political. In this process it is extremely important that people's living standards are improved. People can be become happy individuals based on improved living standards. In this context happiness economics that associates with economic development is an important topic and has drawn attention in recent years. Happiness economics is interested in how the public policies that increase the happiness of individuals will be made. Happiness economics examines how economic development affects individual wellbeing as a consequence of macroeconomic policies. Within this scope gross national happiness came into question in 1972 for the first time in Kingdom of Bhutan. Gross national happiness has taken an important place in the literature of happiness economics. Gross national happiness consists of nine indicators. These are psychological wellbeing, health, time use, education, cultural diversity and resilience, good governance, community vitality, ecological diversity and resilience and living standard.

The study is a qualitative research that evaluates the role of gross national happiness in economic development in the context of the Bhutan Kingdom. The study is based on secondary sources, reports and findings with gross national happiness. In this study the role of gross national happiness in the economic development is examined within the framework Kingdom of Bhutan example.

Key Words: Development, Economic Development, Happiness, Gross National Happiness, Happiness Economics

\footnotetext{
${ }^{1}$ Bu çalışma, 27-29 Temmuz 2017 tarihleri arasında Adnan Menderes Üniversitesi Aydın İktisat Fakültesi tarafindan Aydın'da düzenlenen "2017 EUREFE” isimli kongrede sözlü bildiri olarak sunulmuştur.

2 Doç. Dr., Muğla Sıtkı Koçman Üniversitesi, İktisadi ve İdari Bilimler Fakültesi İktisat Bölümü, ndeviren@ yahoo.com

3 Doktora Öğrencisi, Muğla Sıtkı Koçman Üniversitesi, Sosyal Bilimler Enstitüsü İktisat Anabilim Dalı, , onyild@hotmail.com
} 


\section{Giriş}

Mutluluğun belirleyicilerini saptamaya yönelik çalışmalar, farklı bakış açılarına göre değişik şekillerde sınıflandırılmışıı. Günümüzde iktisat bilimiyle de ilişkilendirilen mutluluk kavramı ve mutluluğu ölçmeye dayalı araştırmalar, mutluluk ekonomisi çerçevesinde ele alınmaktadır. Mutluluk ekonomisi, kamu ekonomisi dalında yoğun tartışmalar doğuran bir konu olmakla beraber disiplinler arası bir alandır. Mutluluğu etkileyen birçok faktör olmasına bağlı olarak üzerinde uzlaşılmış tek bir mutluluk formülü bulunmamaktadır. Dolayısıyla mutluluğu iktisatla ilişkilendiren literatürdeki çalışmalarda, tek bir modeli öne çıkarmak mümkün değildir (Şeker, 2016: 75). Buna karşın, mutluluk ve iktisatı ilişkilendiren ve mutluluk ekonomisine katkı sağlayan son derece önemli çalışmalar bulunmaktadır. $\mathrm{Bu}$ bağlamda mutluluğu sadece gelire ve ekonomik büyümeye indirgeyen baskın görüşü sarsan çalışmasıyla Richard Easterlin (1974), mutluluk ekonomisi literatüründe bir çıkış noktası kabul edilmektedir. Ardından yapılan çalışmalar, çoğu kez Easterlin Paradoksu'na dayandırılmaktadır.

Ekonomik ve sosyal politikaların amacı nedir sorusuna karşılık insanların açlıkla mücadele ettiği yerlerde ekonomik büyüme, ana amaç olarak dünyaca kabul görmüştür. İnsanların yiyecek ihtiyacı ilk sirada gelirken felsefi boyutlar ikinci sirada gelmektedir. Dolayisıyla insanlar ekonomileri zenginleştikçe, daha fazla zenginliğin getirdiği ihtiyaçları sorgulayacak gücü kendilerinde bulurlar. Easterlin'in (1974) çalışması, bu konu üzerine yoğunlaşarak bir çıkış noktası oluş̧urmuştur. Bu bağlamda daha fazla zenginlik, daha fazla mutluluğu satın alamamaktadır (Blanchflower ve Oswald, 2005: 2).

Çalışmada öncelikle mutluluk ve iktisat ilişkisi ele alınarak mutluluk ekonomisinin kavramsal çerçevesi ve tarihsel gelişiminden söz edilecektir. Çalışmanın devamında mutluluğu ölçmeye yönelik araştırmalara yer verilecektir. Son olarak ekonomik kalkınma bağlamında Gayrisafi Milli Mutluluk değerlendirilerek ekonomik kalkınma açısından Bhutan Krallığı'nda Gayrisafi Milli Mutluluk incelenecektir.

\section{Mutluluk ve İktisat İlişkisi}

Türk Dil Kurumu (TDK) mutluluğu, "bütün özlemlere eksiksiz ve sürekli olarak ulaşılmaktan duyulan kıvanç durumu, ongunluk, kut, saadet, bahtiyarlık" olarak tanımlamıştır (TDK, 2005: 1425). Mutluluk, bireyin bir bütün olarak yaşamından zevk alma derecesi olarak tanımlanmaktadır. Mutluluk, bütün yaşamın bir değerlendirmesini simgelemektedir. Tüm yaşamın değerlendirmesi, bireyin aklında biçimlendirdiği tüm unsurları içermektedir. Bireyin nasıl hissettiği, beklentilerini ne ölçüde karşıladığı gibi tüm unsurlar, bu kapsamda değerlendirilmektedir (Veenhoven, 2004). Mutluluk kavramı; sübjektif mutluluk, memnuniyet, fayda, iyi oluş ve refah ile dönüşümlü olarak kullanılmaktadır. İnsanlar geçmişte daha az mutlu olduğunu ve gelecekte daha fazla mutlu olacağını düşünmektedir. Çünkü, insanlar yaşam döngüsü boyunca güncel arzularla yaşamlarını projelendirmektedir. Buna karşın arzular, artan gelirle gerçekleşse de deneyimlenen mutluluk, planlanan mutluluktan farklılık gösterebilmektedir. Dolayısıyla seçimler, yanlış beklentiler üzerine kurulabilmektedir (Easterlin, 2001).

Easterlin (1974), "Does Economic Growth Improve the Human Lot? Some Empirical Evidence" adlı büyük yankı uyandıran makalesinde, gelir ve mutluluk arasındaki ilişkiyi ele almış ve Easterlin Paradoksu olarak anılan ve kendisinden sonra gelenlere temel oluşturacak bulgulara ulaşmıştır. Easterlin, gelirin belirli bir gelir düzeyini aştıktan sonra mutluluğu arttırma gücünü yitirdiği sonucuna ulaşmaktadır. Easterlin Paradoksu'nu ortaya çıkaran 
çalışmaya göre büyüme ile mutluluk arasında mutlak bir ilişkinin bulunmadığı ve ekonomik büyümenin, insanların temel ihtiyaçlarını karşılayacak eşiği aştıktan sonra mutluluk sağlamadığı bulgularına ulaşılmıştır (Şeker, 2016: 177). Easterlin'e (1974) göre herhangi bir bireyin gelirindeki artış, mutluluğu arttırmakta ancak belirli bir ortalama gelir düzeyinden sonra herkesin gelir düzeyindeki artış, mutluluğu etkilememektedir. Benzer şekilde, ülkeler arasında daha zengin bir ülkenin, daha mutlu olması gerekmemektedir (Easterlin, 1974: 112). Easterlin'in (1974) gelir ve mutluluk arasındaki ilişkiyi ortaya koyan çalışmasında temel veriler, bireylerin sübjektif mutluluk üzerine ifadelerinden oluşmaktadır. 1946'den 1970'e kadar 30 anket raporlanarak 19 ülkeyi kapsayan bir çalışma gerçekleştirilmiştir. Bu çalışmada ülke içerisinde yer alan en yüksek statü grubundakilerin, ortalama olarak en düşük statü grubundakilere göre daha mutlu olduğu sonucuna varılmıştır. Buna karşın, belirli bir zamanda ülkeler arasında böyle bir pozitif ilişki olup olmadığ 1 belirsizdir. Benzer şekilde, ABD'de 1946'dan itibaren daha yüksek gelirin daha fazla mutluluğu beraberinde getirmediği görülmüştür. Ayrıca çalışmada Duesenberry Modeli'nde olduğu gibi göreceli durumun mutluluğun önemli bir belirleyicisi olma düşüncesi, öne çıkmıştır. Easterlin mutluluk değerlendirmesinde insanların fiili durumunu referans standartlarla ve normlarla karşılaştırma eğiliminde olup, mutlulukların önceki ve süregelen sosyal deneyimlerden de edindiği üzerinde durulmuştur (Easterlin, 1974: 118). Dolayısıyla bir toplumda gelir düzeyi yüksek olanların mutlu olmasına karşın aynı toplumdaki kişi başına düşen gelirin artması, insanların mutluluğu toplum içindeki göreceli durumdan yakından etkilendiği için ortalama mutluluk düzeyini arttırmamaktadır. Mutluluk Paradoksu olarak nitelenen bu duruma göre aynı toplumda belirli bir zaman diliminde gelir düzeyi yüksek olanlar, diğerlerine göre daha mutlu iken tüm toplumun gelirinin artması, mutluluk düzeyini arttırmamaktadır (Demir, 2013: 207).

Tian ve Yang (2006) çalışmasında, kritik bir gelir düzeyinden söz etmektedir. Artan gelirin mutluluğu olumlu etkilemesine karşın kritik gelir düzeyi aşıldığında gelir artışı, sosyal mutluluğu arttırmamaktadır. Sosyal mutluluk, azalmaktadır ve Pareto etkinsizliğiyle sonuçlanmaktadır.

Stevenson ve Wolfers (2008), Easterlin Paradoksunun toplumun ekonomik kalkınması ve ortalama mutluluk düzeyi arasında bir bağlantı bulunmadığına dair bulgusunu yeniden değerlendirmişlerdir. Bu çalışmada, ortalama sübjektif mutluluk düzeyi ile Kişi Başına Gayrisafi Yurtiçi Hasıla arasında açıkça bir ilişki bulunmuştur. Ekonomik büyüme, artan mutlulukla ilişkilendirilmiş ve Easterlin Paradoksunun aksine bulgulara ulaşılmıştır.

Kahneman ve Deaton (2010), yürütülen araştırmalarda sübjektif mutluluğun iki yönüyle sivrilmeye başladığını ifade etmişlerdir. Bunlar duygusal mutluluk ve yaşam değerlendirmesidir. Duygusal mutluluk, bireylerin günlük deneyimlerindeki duygusal niteliğe vurgu yapmaktadır. Yaşanan sevinçlerin yoğunluğu ve sıklığı, stres, üzüntü, öfke ve birilerinin yaşamından duyulan memnuniyet ya da memnuniyetsizlik, duygusal mutluluk kapsamında değerlendirilebilir. Yaşam değerlendirmesi ise insanların hayatları hakkındaki düşüncelerine işaret etmektedir. Bu çalışmada paranın mutluluğu satın alıp almadığına ilişkin soruya yanıt aranmıştır. Ayrıca, duygusal mutluluk ve yaşam değerlendirmesi farklı ilişkilendirilmiştir. Gelir ve eğitim, yaşam değerlendirmesiyle daha yakın ilişkilendirilirken sağlık ve yalnızlık, günlük duygularla daha kuvvetli ilişkilendirilmiştir (Kahneman ve Deaton, 2010: 16489). Çalışmadan elde edilen sonuçlara göre daha fazla paranın, daha çok mutluluk getirmesi zorunlu değildir ancak daha az para, duygusal 1zdırapla ilişkilidir. $\mathrm{Bu}$ bağlamda 75.000 dolar eşiğini aştıktan sonra gelir, duygusal mutluluğun belirleyicisi olmamaktadır (Kahneman ve Deaton, 2010: 16492). 


\section{Mutluluk Ekonomisinin Kavramsal Çerçevesi ve Tarihsel Gelișimi}

Mutluluğu insan yaşamının amacı olarak niteleyen Aristo'ya göre her insan mutluluğu aramaktadır. Mutluluğun insan yaşamının ana amacını oluşturduğun söyleyen Aristoteles, "Nikomakhos Etiğì" adlı eserinde bilge ya da cahil, zengin ya da fakir çoğu insanın ana gayesi olarak mutluluğu görmektedir. Mutluluk, bir araç olarak değil, yüce bir amaç doğrultusunda açıklanmıştır. Mutluluk kelimesini iyi kelimesiyle özdeşleştiren Aristoteles, bireye mutluluk getirecek iyi hayatın objektif akıl yoluyla bulunabileceğini öne sürmüştür. Farabi de benzer şekilde mutluluk kavramını insanın yüce bir amaç olarak ulaşabileceği en yüksek iyilik şeklinde açıklamıştır. Sokrates de mutluluğu en üstün iyi olma durumu olarak açıklamış ve mutluluğun bilgi yoluyla elde edileceğini ifade etmiştir. Hazcı (Hedonik) felsefeyi benimseyen Bentham ise insanın bir şey yaptığı sırada kendisini iyi hissetmesinin önemini vurgulamış ve insanın ne yaptığından ziyade kendisini ne kadar iyi hissettiğine odaklanmıştır (Şeker, 2016: 15-16). Bentham'ın faydacı felsefesi, 3 ilkeye dayanmaktadır. Birincisi, bireyin mutluluğu, aldığı zevklerin artması ve çektiği acıların azalması olarak tanımlanır. İkincisi, birey için nihai iyinin mutluluk olduğu iddia edilir. Dolayısıyla insanların istekleri, mutlu olmak için birer araç niteliğindedir. Üçüncüsü ise her bireyin esasen istediği mutluluksa toplum için en iyi olan da çok sayıda insanı mutlu edecek bir düzendir. Faydacıların amacı, bu ilkeler çerçevesinde çoğunluğun mutluluğunu arttıracak politik reformların yapılmasını sağlamaktır. Bentham'a göre her bireyin sübjektif mutluluğu, nesnel bir şekilde (zevklerin yoğunluk süresi vb.) ölçülebilir ve toplumun mutluluğu hesaplanırken her bireyin mutluluğu eşit olarak değerlendirilebilir (Mill, 2017: 28-29).

Bentham'ın ve izinden gidenlerin etkisiyle özellikle Batı Avrupa'da yapılan toplumsal düzenlemeler, önemli ölçüde faydacı düşünce temelinde gerçekleşmiştir. İktisadi düşünce sisteminin de söz konusu faydacı düşünce temeli çerçevesinde şekillenmesi, doğal bir süreç olarak değerlendirilebilir. Faydacı düşünceden hareketle benimsenen varsayımlar, iktisadi analizlere de temel teşkil etmiştir. J.S. Mill'in de katkılarıyla faydacılık, 19. Yüzyıl sonlarında gerçekleşen marjinalist devrime bağlı olarak altın yıllarını yaşamıştır (Şeker ve Çetin, 2012: 282).

Adam Smith, John Stuart Mill, Jeremy Bentham gibi klasik iktisatçılar, çalışmalarında mutluluğa dair düşüncelere yer vermişlerdir. Buna karşın, iktisat bilimi zamanla giderek daha katı ve matematiksel olma yolunda ilerlemiş ve refahı daha dar kapsamda ele almıştır. Böylece fayda, sadece gelire bağlı olarak düşünülmüş ve bireysel tercihler, kısıtlı bir bütçeyi rasyonel kullanmak ön plana çıkmıştır. Yakın dönemde ise mutluluk iktisatçıların ilgisini yeniden çekerek ön plana çıkmıştır (Veenhoven ve Dumludağ, 2015). Faydacı yaklaşım, refah ekonomisinde uzun bir süre etkinliğini sürdürmesine rağmen zaman içerisinde refah ekonomisini açıklamada yetersiz kalmıştır. Özellikle ülkedeki gelir düzeyi artarken her insanın ek gelir artışına tepkisinin farklı olacağı görüşü ve bireysel tercihlerin karşılaştırılabilir olmasına yönelik düşünceler, standart iktisat teorisindeki faydaya yönelik yaklaşımı sorgulanır hale getirmiştir. Buradan hareketle davranışsal iktisat alanında fayda fonksiyonunun önemi vurgulanarak fayda fonksiyonunun, bireylerin kendi tüketiminin yanı sıra başkalarının tüketiminden de etkilendiği ileri sürülmüştür. Duesenbery (1949)'de birbirine bağımlı tercihlerin bireysel tüketim ve tasarruf üzerindeki etkisini ampirik olarak test etmiştir. İktisat politikalarının faydanın göreceli olmasını dikkate alması, büyük önem taşımaktadır (Dumludağ, 2014: 370-371). Çağdaş ekonomi biliminde mutluluğa ilişkin iki temel yaklaşım olarak tercih memnuniyeti ile sübjektif mutluluk, belirli ana varsayımları paylaşmaktadır. Özellikle her iki yaklaşım da genel olarak dış kriterleri veya kararları reddetmekte, bireyi kendi mutluluğunu değerlendirmeye yetkili tek kişi olarak ayrıcalıklı 
kılmaktadır. Her iki yaklaşımda eşitlikçi, liberal politik görüşlere potansiyel uyumluluk sağlamaktadır (Mac Kerron, 2012: 706).

Ortodoks yaklaşımda fayda, rasyonel bireyin bütçe kısıtı altında sadece gelirine bağlı iken yeni bir yaklaşım olan mutluluk ekonomisi, daha geniş bir fayda ve refah görüşüne dayanmaktadır. $\mathrm{Bu}$ görüş rasyonel olan ve olmayan etkileri de ortaya koymaya çalışmaktadır. Mutluluk ekonomisi, sosyo-ekonomik unsurlardan ziyade makroekonomik politikaların sonucu olan ekonomik büyüme, işsizlik, enflasyon gibi ekonomik unsurları ve iyi yönetişim gibi kurumsal faktörlerin bireylerin refahından hareketle mutluluğu nasıl etkilediğini incelemektedir (Şimşir, 2013: 8).

\section{Mutluluğu Ölçmeye Yönelik Araştırmalar}

Mutluluğa ilişkin olarak gerçekleştirilen araştırmalardan geçmişten günümüze kadar süreklilik gösteren önemli bir çalışma, İsveç merkezli Dünya Değerler Araştırması'dır. 1981'den itibaren belirli dönemlere göre yürütülen araştırma, ilk olarak 1981-1984 dönemi için gerçekleştirilmiştir. Bu araştırma; 1990-1994 dönemi, 1995-1998 dönemi, 1999-2004 dönemi, 2005-2009 dönemi ve 2010-2014 dönemleri için de gerçekleştirilmiştir. Ancak 1999-2004 dönemindeki araştırmada "hissedilen mutluluk" sorusu deneklere yöneltilmemiştir. Dünya Değerler Araştırmasında hissedilen mutluluk sorusuna aranan cevaplar "çok mutlu, oldukça mutlu, mutlu değil, hiç mutlu değil" şeklindedir. Tablo 1'de 2010-2014 dönemi için hissedilen mutluluk, ülkeler itibariyle gösterilmektedir.

\section{Tablo 1. Dünya Değerler Araştırması - Hissedilen Mutluluk Oranları (2010-2014)}

\begin{tabular}{|c|c|c|c|}
\hline ÜLKELER & Çok Mutlu (\%) & $\begin{array}{c}\text { Oldukça Mutlu } \\
(\%)\end{array}$ & Toplam (\%) \\
\hline 1. Katar & 56,4 & 41,6 & 98,0 \\
\hline 2. Özbekistan & 64,5 & 31,5 & 96,0 \\
\hline 3. Malezya & 56,5 & 39,5 & 96,0 \\
\hline 4. Kirg1zistan & 36,2 & 59,7 & 95,9 \\
\hline 5. İsveç & 40,5 & 54,1 & 94,6 \\
\hline 6. Meksika & 67,5 & 26,8 & 94,3 \\
\hline 7. Ekvador & 57,7 & 35,3 & 93,0 \\
\hline 8. Singapur & 39,1 & 53,9 & 93,0 \\
\hline 9. Tayland & 39,7 & 53,3 & 93,0 \\
\hline 10. Avustralya & 34,9 & 57,7 & 92.6 \\
\hline 12. Hollanda & 31,9 & 60,5 & 92,4 \\
\hline 14. Brezilya & 35,2 & 56,8 & 92,0 \\
\hline 18. G. Kore & 15,2 & 74,8 & 90,0 \\
\hline 20. ABD & 36,1 & 53,5 & 89,6 \\
\hline 26. Japonya & 32,3 & 54,2 & 86,5 \\
\hline 27. Arjantin & 33.3 & 53.1 & 86.4 \\
\hline 28. İspanya & 15,5 & 70,9 & 86,4 \\
\hline 33. Çin & 15,7 & 68,8 & 84,5 \\
\hline 35. Almanya & 23,1 & 60,9 & 84,0 \\
\hline 36. Türkiye & 37,5 & 46,3 & 83,8 \\
\hline 56. Romanya & 13,6 & 55,4 & 69,0 \\
\hline 57. Ukrayna & 16,1 & 52,0 & 68,1 \\
\hline 58. Irak & 10,5 & 57,5 & 68,0 \\
\hline 59. Belarus & 10,6 & 53,1 & 63,7 \\
\hline 60. Misir & 5,3 & 20,7 & 26,0 \\
\hline
\end{tabular}

Kaynak: World Values Survey, 2015 
Tablo 1'e göre hissedilen mutluluk sorusuna verilen cevaplardan hareketle ilk sıray1 Katar alırken Özbekistan ikinci ve Malezya 3.sırada yer almıştır. Türkiye'nin kendine 36. Sırada yer bulduğu araştırmada, ABD 20. olurken Çin 33. ve Almanya 35.sırada yer almıştır. Son sirada ise Misır bulunmaktadır.

Leicester Üniversitesi'nden White (2007), ele aldığı çalışmada dünyanın mutluluk haritasını çıkarmıştır. White'ın çalışması, 178 ülkeyi kapsamaktadır. Bu çalışmaya göre en mutlu ülke Danimarka olurken Danimarka'yı İsviçre, Avusturya, İzlanda, Bahamalar, Finlandiye ve İsveç takip etmiştir. Bhutan Krallığ 1 ise mutluluk haritasında bu ülkelerinden ardından sekizinci sırada yer almıştır. Türkiye de mutluluk haritasında kendine 133. sıradan yer bulmuştur. Bu haritada Hollanda 15., Norveç 19., ABD 23., Almanya 35., Birleşik Krallık 41., Katar 45., İsrail 58., Fransa 62., Hong-Kong 63., Tayvan 68., Brezilya 81., Çin 82., Yunanistan 84., Japonya 90., İran 96., Güney Kore 103., Rusya 167. siradadır. Haritada en mutsuz ülke Burundi olurken Burundi'ye en çok yaklaşan ülkeler sırasıyla Zimbabwe ve Demokratik Kongo Cumhuriyeti'dir. Mutluluk haritasında, sübjektif mutluluğun uluslararası seviyesi sunulmaktadır. Sübjektif mutluluğa ilişkin veriler, meta-analiziyle çıkarılmıştır. Küresel mutluluk haritasının ilk defa yayınlandığını ifade eden White, yoksulluğun sübjektif mutluluk seviyesi üzerindeki etkileri üzerinde durmuştur. Sübjektif mutluluk verileri eğitime erişim, sağlık ve yoksulluk verileriyle karşılaştırılmaktadır. Sübjektif mutluluğun, sağlıkla çok güçlü ilişkisi olduğu ve zenginlik ile temel eğitime erişimin, bunu yakından takip ettiği görülmüştür. Ayrıca, çalışmada sübjektif mutluluğun küresel perspektifte en büyük nedeninin yoksulluk ve ilişkili değişkenler olduğu da belirtilmiştir (White, 2007).

Yeni İktisat Vakfı'nın (New Economic Foundation) ele aldığı çalışmada, Mutlu Gezegen Endeksi (Happy Planet Index) geliştirilmiştir. 2006'dan itibaren açılanan araştırma 2009, 2012 ve 2016 yıllarında da açıklanarak süreklilik göstermiştir. Mutlu Gezegen Endeksi, ülkelerin uzun, mutlu ve sürdürülebilir yaşamı başarmada ne kadar iyi olabileceğine açıklık getirmektedir. Mutlu Gezegen Endeksi, ülkelere rehber olabilecek bir pusula sağlamakta ve dünyaya maliyeti olmaksızın iyi bir hayat yaşamanın mümkün olduğunu göstermektedir. $\mathrm{Bu}$ bağlamda, farklı ülkelerde yaşayan insanlara uzun ve mutlu bir yaşam sürmek için çevresel kaynakları nasıl etkin bir şekilde kullanacağını göstermek için dört tane değişkeni kombine etmiştir. Söz konusu değişkenler; mutluluk (İyi olma hali), yaşam beklentisi, çıktıların eşitsizliği ve ekolojik ayak izidir (NEF, 2016). Mutlu Gezegen Endeksi, sürdürülebilir mutluluğu ölçmede öncülük yapmaktadır. Buna karşın, hiçbir ülke yüksek derecede mutluluğun ve uzun yaşamın nihai hedeflerine sürdürülebilir ekolojik sınırlar içerisinde ulaşamamıştır. 140 ülkeyi kapsayan araştırmada hiçbir G8 ülkesi, bu sıralamada ilk 30 içinde yer almamıştır. Küçük tropikal bir ülke olan Kosta Rika, bu sıralamada üçüncü kez ilk sırada yer alarak batılı ekonomilere üstünlük kurmuştur (Jeffrey, 2016). 2016'ya ilişkin Mutlu Gezegen Endeksine ait veriler, Tablo 2'de yer almaktadır. 
Tablo 2. Seçilmiş Ülkeler İtibariyle Mutlu Gezegen Endeksi Sonuçları (2016)

\begin{tabular}{|c|c|c|c|c|c|c|}
\hline Sura & Ülke & $\begin{array}{c}\text { Mutlu } \\
\text { Gezegen } \\
\text { Endeksi }\end{array}$ & $\begin{array}{c}\text { Mutluluk (10 } \\
\text { üzerinden) }\end{array}$ & $\begin{array}{c}\text { Yaşam } \\
\text { Beklentisi }\end{array}$ & $\begin{array}{c}\text { Çıktıların } \\
\text { Eşitsizliği } \\
(\%)\end{array}$ & $\begin{array}{l}\text { Ekolojik } \\
\text { Ayak İzi }\end{array}$ \\
\hline 1 & Kosta Rika & 44,7 & 7,3 & 79,1 & 15 & 2,8 \\
\hline 2 & Meksika & 40,7 & 7,3 & 76,4 & 19 & 2,9 \\
\hline 3 & Kolombiya & 40,7 & 6,4 & 73,7 & 24 & 1,9 \\
\hline 4 & Vanuatu & 40,6 & 6,5 & 71,3 & 22 & 1,9 \\
\hline 5 & Vietnam & 40,3 & 5,5 & 75,5 & 19 & 1,7 \\
\hline 6 & Panama & 39,5 & 6,9 & 77,2 & 19 & 2,8 \\
\hline 7 & Nikaragua & 38,7 & 5,4 & 74,3 & 25 & 1,4 \\
\hline 8 & Bangladeş & 38,4 & 4,7 & 70,8 & 27 & 0,7 \\
\hline 9 & Tayland & 37,3 & 6,3 & 74,1 & 15 & 2,7 \\
\hline 10 & Ekvador & 37,0 & 6,0 & 75,4 & 22 & 2,2 \\
\hline 12 & Norveç & 36,8 & 7,7 & 81,3 & 7 & 5,0 \\
\hline 18 & Hollanda & 35,3 & 7,5 & 81,2 & 4 & 5,3 \\
\hline 19 & Arjantin & 35,2 & 6,5 & 75,9 & 16 & 3,1 \\
\hline 22 & Filistin & 34,5 & 4,6 & 72,6 & 24 & 1,2 \\
\hline 23 & Brezilya & 34,3 & 6,9 & 73,9 & 22 & 3,1 \\
\hline 24 & İsviçre & 34,3 & 7,8 & 82,6 & 6 & 5,8 \\
\hline 32 & Danimarka & 32,7 & 7,5 & 79,8 & 7 & 5,5 \\
\hline 34 & Birleşik Krallık & 31,9 & 6,9 & 80,4 & 9 & 4,9 \\
\hline 37 & Finlandiya & 31,3 & 7,4 & 80,4 & 6 & 5,9 \\
\hline 44 & Fransa & 30,4 & 6,6 & 81,8 & 9 & 5,1 \\
\hline 49 & Almanya & 29,8 & 6,7 & 80,6 & 8 & 5,3 \\
\hline 51 & Özbekistan & 29,1 & 6,0 & 68,2 & 30 & 2,3 \\
\hline 56 & Bhutan Krallığg & 28,6 & 5,6 & 68,7 & 27 & 2,3 \\
\hline 58 & Japonya & 28,3 & 6,0 & 83,2 & 9 & 5,0 \\
\hline 61 & İsveç & 28,0 & 7,6 & 81,8 & 6 & 7,3 \\
\hline 68 & Türkiye & 26,4 & 5,3 & 74,7 & 19 & 3,3 \\
\hline 72 & Çin & 25,7 & 5,1 & 75,4 & 17 & 3,4 \\
\hline 80 & G. Kore & 24,8 & 6,0 & 81,3 & 11 & 5,7 \\
\hline 84 & İran & 24,0 & 4,6 & 74,8 & 23 & 2,8 \\
\hline 89 & Yunanistan & 23,6 & 5,1 & 80,5 & 16 & 4,4 \\
\hline 108 & $\mathrm{ABD}$ & 20,7 & 7,0 & 78,8 & 13 & 8,2 \\
\hline 113 & Suriye & 19,1 & 3,2 & 70,4 & 30 & 1,5 \\
\hline 116 & Rusya & 18,7 & 5,6 & 69,5 & 16 & 5,7 \\
\hline 138 & Togo & 13,2 & 2,9 & 58,6 & 43 & 1,1 \\
\hline 139 & Lüksemburg & 13,2 & 7,0 & 81,1 & 7 & 15,8 \\
\hline 140 & $\mathrm{Cad}$ & 12,8 & 4,0 & 50,8 & 51 & 1,5 \\
\hline
\end{tabular}

Kaynak: WEF, 2016 
Mutlu Gezegen Endeksi; Gayrisafi Yurtiçi Hasıla ile İnsani Gelișme Endeksinde göz ardı edilen sürdürülebilirliğe atfettiği değer itibariyle önem taşımaktadır. Bireyin ve toplumun refahı söz konusu olduğunda küresel açıdan ekolojik maliyetler, birçok mutluluk araştırmasında ihmal edilmiştir (Cingi, 2011). Sürdürülebilirliği gözetmesi, Mutlu Gezegen Endeksini ayırt edici kılmaktadır. Mutlu Gezegen Endeksi sonuçlarına göre ilk 5 sırayı oluşturan ülkeler sirasıyla Kosta Rika, Meksika, Kolombiya, Vanuatu ve Vietnam'dır. Lüksemburg; mutluluk, yaşam beklentisi ve çıktıların eşitsizliği değişkenlerinde olumlu sonuçlara sahip olmasına karşın ekolojik ayak izindeki kötü derecesine bağlı olarak 140 ülke arasında 139. sırada yer alabilmiştir.

Birleşmiş Milletler tarafindan hayata geçirilen küresel bir girişim olan "Sustainable Development Solutions Network" (Sürdürülebilir Kalkınma Çözümleri Ağı) tarafından John Helliwell, Richard Layard ve Jeffrey Sachs'ın editörlügünde hazırlanan ve 2014-2016 yıllarını kapsayan "Dünya Mutluluk Raporu'na (World Happiness Report) göre araştırmada ilk sırada Norveç yer almaktadır. Norveç'i ise Danimarka ve İzlanda takip etmektedir. 155 ülkeyi kapsayan mutluluk sıralamasında Türkiye 69. olurken Bhutan Krallığı ise 97. sırada yer almıştır. Son sırada ise Orta Afrika Cumhuriyeti yer almaktadır. Dünya Mutluluk Raporu'na göre belirlenen mutluluk sıralaması, Tablo 3'de seçilmiş ülkeler itibariyle gösterilmektedir. 
Tablo 3. Seçilmiş Ülkeler İtibariyle Dünya Mutluluk Raporu Endeksleri (2014-2016)

\begin{tabular}{|l|l|l|}
\hline SIra & Ülke & Dünya Mutluluk Raporu Endeksi \\
\hline 1 & Norveç & 7,537 \\
\hline 2 & Danimarka & 7,522 \\
\hline 3 & İzlanda & 7,504 \\
\hline 4 & İsiçre & 7,494 \\
\hline 5 & Finlandiya & 7,469 \\
\hline 6 & Hollanda & 7,377 \\
\hline 7 & Kanada & 7,316 \\
\hline 8 & Yeni Zelanda & 7,314 \\
\hline 9 & Avustralya & 7,284 \\
\hline 10 & İsveç & 7,284 \\
\hline 11 & İsrail & 7,213 \\
\hline 12 & Kosta Rika & 7,079 \\
\hline 14 & ABD & 6,993 \\
\hline 16 & Almanya & 6,951 \\
\hline 18 & Lüksemburg & 6,863 \\
\hline 19 & Birleşik Krallık & 6,714 \\
\hline 22 & Brezilya & 6,635 \\
\hline 24 & Arjantin & 6,599 \\
\hline 26 & Singapur & 6,572 \\
\hline 31 & Fransa & 6,442 \\
\hline 35 & Katar & 6,375 \\
\hline 47 & Özbekistan & 5,971 \\
\hline 49 & Rusya & 5,963 \\
\hline 51 & Japonya & 5,920 \\
\hline 56 & G. Kore & 5,838 \\
\hline 69 & Türkiye & 5,500 \\
\hline 71 & Hong-Kong & 5,472 \\
\hline 79 & Çin & 5,273 \\
\hline 87 & Yunanistan & 5,227 \\
\hline 94 & Vietnam & 5,074 \\
\hline 97 & Bhutan Krallı̆ 1 & 5,011 \\
\hline 101 & G. Afrika & 4,829 \\
\hline 108 & İran & 4,692 \\
\hline 110 & Bangladeş & 4,608 \\
\hline 152 & Suriye & 3,462 \\
\hline 153 & Tanzanya & 3,349 \\
\hline 154 & Burundi & 2,905 \\
\hline 155 & Orta Afrika & 2,693 \\
\hline & Cumhuriyeti & \\
\hline & Kaynak: Hellwell \\
\hline
\end{tabular}

Kaynak: Helliwell vd., 2017: 20-22

Dünya Mutluluk Raporu Araştırması'nda mutluluk sıralamasını belirlemek için kullanılan bağımsız değişkenler ise kişi başına düşen Gayrisafi Yurtiçi Hasıla, sosyal destekler, doğumda sağlıklı yaşam beklentisi, hayatta seçim yapma özgürlüğü, cömertlik, yolsuzluk algısı, pozitif etkiler ve negatif etkilerdir (Helliwell vd., 2017: 16). 
Tablo 4. Seçilmiş Ülkeler İtibariyle Yaşam Memnuniyetine İlişkin Dünya Mutluluk Veri Tabanı (2005-2014)

\begin{tabular}{|l|l|l|}
\hline Sira & Ülke & Yaşam Memnuniyeti (0-10) \\
\hline 1 & Kosta Rika & 8,5 \\
\hline 2 & Danimarka & 8,4 \\
\hline 3 & Meksika & 8,3 \\
\hline 4 & İzlanda & 8,1 \\
\hline 5 & İsviçre & 8,0 \\
\hline 6 & Kanada & 8,0 \\
\hline 7 & Norveç & 8,0 \\
\hline 8 & Finlandiya & 7,9 \\
\hline 9 & Kolombiya & 7,9 \\
\hline 10 & İsveç & 7,8 \\
\hline 13 & Lüksemburg & 7,7 \\
\hline 14 & Hollanda & 7,6 \\
\hline 20 & ABD & 7,3 \\
\hline 21 & İsrail & 7,3 \\
\hline 22 & Katar & 7,3 \\
\hline 23 & Almanya & 7,2 \\
\hline 30 & Birleşik Krallik & 7,1 \\
\hline 31 & Arjantin & 7,1 \\
\hline 40 & Brezilya & 6,9 \\
\hline 41 & Özbekistan & 6,8 \\
\hline 58 & Yunanistan & 6,5 \\
\hline 62 & Japonya & 6,4 \\
\hline 63 & Fransa & 6,4 \\
\hline 64 & Tayvan & 6,4 \\
\hline 69 & Çin & 6,2 \\
\hline 74 & G. Kore & 6,1 \\
\hline 77 & Türkiye & 6,0 \\
\hline 94 & Bhutan Krallı̆ 1 & 5,6 \\
\hline 95 & Rusya & 5,6 \\
\hline 156 & Burundi & 2,9 \\
\hline 157 & Togo & 2,6 \\
\hline 158 & Tanzanya & 2,5 \\
\hline & & Keenhoven \\
\hline
\end{tabular}

Kaynak: Veenhoven, 2015

Hollanda'daki Rotterdam Erasmus Üniversitesi'nden Ruut Veenhoven'ın yürüttüğü 20052014 dönemine ait ortalama mutluluk değerlerine dayanarak oluşturulan World Happiness Database (Dünya Mutluluk Veritabanı) adlı araştırma, 158 ülkeyi kapsamaktadır. Veenhoven (2015)'ın çalışması seçilmiş ülkeler itibariyle Tablo 4'de gösterilmektedir. Veenhoven'in (2015) araştırmasına göre Kosta Rika ilk sırada yer alırken Türkiye 77., Bhutan Krallığı ise 94. sırada yer almıştır.

Türkiye'de TÜIKK tarafindan yürütülen Yaşam Memnuniyeti Araştırması'nda ise mutlu olduğunu beyan eden bireylerin oran1, 2015 yılında \%56,6 iken 2016 yılında \%61,3 olarak gerçekleşmiştir. Mutsuz olduğunu beyan eden bireylerin oranı ise $\% 11,4$ 'ten $\% 10,4$ 'e düşmüştür. Kadınlarda mutluluk oranı, 2015 yılında \%60,2 iken 2016 yılında \%64,5'e, erkeklerde ise bu oran, $\% 52,9$ 'dan $\% 58,1$ 'e yükselmiştir. Yaş gruplarına göre mutluluk düzeyine bakıldığında, 2016 yılında en yüksek mutluluk oranı $\% 65,1$ ile 18-24 yaş grubunda, en düşük mutluluk oranı ise \%58,2 ile 35-44 yaş grubunda gerçekleşmiştir (TÜíK, 2017). 


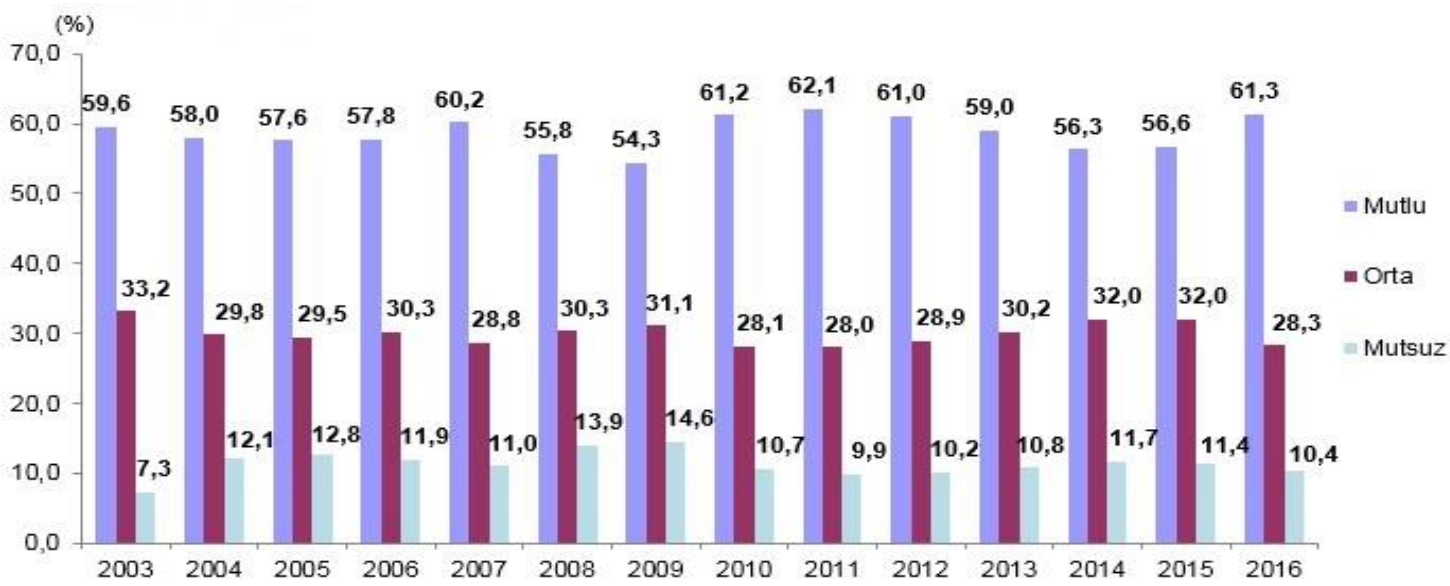

\section{Şekil 1: Türkiye'de Genel Mutluluk Düzeyi}

Kaynak: TÜIK, 2017

Söz konusu Yaşam Memnuniyeti Araştırmasi; bireylerin genel mutluluk algısını, toplumsal değer yargılarını, temel yaşam alanlarındaki genel memnuniyetini ve kamu hizmetlerinden memnuniyetini ölçmek, memnuniyet düzeylerinin zaman içindeki değişimini takip etmek amacıyla 2003 yılından itibaren düzenli olarak gerçekleştirilmektedir. Araştırmanın sonuçlarına göre kendilerini en çok sağlıklı olmanın mutlu ettiğini ifade edenlerin oranı, $\% 72,1$ olurken bunu sırasıyla $\% 14,6$ ile sevgi, $\% 7$ ile başarı, $\% 3,2$ ile para, $\% 2,3$ ile iş ve $\% 0,8$ ile diğer değerler takip etmiştir (TÜİK, 2017).

\section{Ekonomik Kalkınma Bağlamında Gayrisafi Milli Mutluluk}

Bhutan Krallığı, mutluluğu ekonomik kalkınmada belirleyici bir gösterge olarak görmekte ve ülkelerin kalkınmışlık derecelerinin, Gayrisafi Yurtiçi Hasıla yerine Gayrisafi Milli Mutluluk ile ifade edilmesi gerektiğini ileri sürmektedir. Buradan hareketle 1972'de ortaya çıkan Gayrisafi Milli Mutluluk kavramı, maneviyata dayalı olup Budist değerleri gözetmektedir. Genel refah ve çevreyi koruma gibi hedefler, Budist değerlerin etkisiyle değerlendirmeye alınmıştır (Gökdemir ve Veenhoven, 2014: 358). Gayrisafi Milli Mutluluk, Gayrisafi Yurtiçi Hasıla'nın içermediği piyasa dışı katkıları da kapsamaktadır. Gayrisafi Milli Mutluluk, Gayrisafi Yurt İçi Hasıla'ya tam bir ikame olmasa da tamamlayıcısı olarak kabul görmektedir. Geleneksel kalkınma modellerinden farklı olarak Gayrisafi Milli Mutluluk, çevresel değerleri de bünyesinde barındırmaktadır (Cingi, 2011:133-134).

Gayrisafi Yurtiçi Hasıla, belirli bir zamanda bir ekonomide üretilen mal ve hizmetlerin toplam piyasa değerini ölçmek amacıyla yaratılmıştır. Gayrisafi Yurtiçi Hasıla, sosyal refah üzerine odaklanmamıştır. Gayrisafi Yurtiçi Hasıla, gerçek refah toplumunun bileşenlerinin birçoğunu elde etmede başarısız olmaktadır. Bu gösterge, sosyal gelişmenin bir ölçütü olabilir ancak bazı kusurlara sahiptir. Örneğin, "1999 yılından 2007 yılına kadar ABD'de Gayrisafi Yurtiçi Hasıla, istikrarlı şekilde artmakla birlikte birçok Amerikalı, 2007 yılında 1999 yılına göre daha çok yoksullaşmıştır. Gayrisafi Yurtiçi Hasıla, istikrarlı bir şekilde artsa bile birçok Amerikalı için yaşam standartlarında genel bir azalma ortaya çıkmıştır. Gayrisafi Yurtiçi Hasıla ile karşılaştırıldığında Gayrisafi Milli Mutluluk, hükümet tarafından göz ardı edilmemesi gereken refah ögesi üzerine odaklanmaktadır. Sosyal gelişme, Gayrisafi Yurtiçi Hasıla yoluyla yansitılmakla beraber şu sorunun sorulma ihtiyaci duyulmaktadır: 
"Vatandaşlar için gelişme, neyi ifade etmektedir?" Gayrisafi Yurtiçi Hasıla'dan ziyade maksimum Gayrisafi Milli Mutluluğu gerçekleştirmeye çalışan bir ülke olarak Bhutan, vatandaşlarının refahı ve mutluluğuna daha fazla önem vererek daha bütüncül ve sürdürülebilir bir kalkınma yaklaşımı seçmiştir (Chen, 2015: 71).

\section{Ekonomik Kalkınma Açısından Bhutan Krallığı'nda Gayrisafi Milli Mutluluk}

Önceki Bhutan Kralı Jigme Singye Wangchuck, 1972 yılında Bhutan Krallığı'nın kalkınmasının ana felsefesi olarak Gayrisafi Milli Mutluluk kavramını önermiştir. Kraliyet; ekonomik kalkınma, kültür, yönetim ve manevi değerleri ölçmek için Gayrisafi Milli Mutluluğu kullanmaktadır. Bhutan Krallığı için mutluluk, Batı literatüründeki mutluluktan farklı1ık gösterir. Birincisi Bhutan halk1, mutluluğu sübjektif ve tekli şekilde dikkate almaktan ziyade objektif şekilde dikkate almaktadır. İkincisi, Bhutan halkı mutluluğu, sorumluluklar ve diğer ilgili güdüleri açık bir şekilde içselleştirme olarak tanımlamıştır (Chen, 2015: 66).

Gayrisafi Milli Mutluluk endeksi, dokuz alanda geliştirilen 33 göstergenin analizine dayalı ve Alkire-Foster Metodu olarak bilinen güçlü ve çok boyutlu bir endekstir. Gayrisafi Milli Mutluluk endeksi, temelde insanların 33 göstergenin temsil ettiği farklı talepleri karşılama derecesini yansitan Gayrisafi Milli Mutluluğun politik teşvikler yoluyla arttırılması için geliştirilmiştir. Bu 33 gösterge ile ağırlıkları, Tablo 5'de gösterilmektedir.

Tablo 5. Gayrisafi Milli Mutluluk Endeksi Göstergeleri

\begin{tabular}{|c|c|c|c|c|c|}
\hline Alan & Göstergeler & Ăğırlık & Alan & Göstergeler & Ăğırlık \\
\hline \multirow{4}{*}{$\begin{array}{c}\text { Psikolojik İyilik } \\
\text { Hali }\end{array}$} & Yaşam memnuniyeti & $33 \%$ & \multirow{4}{*}{$\begin{array}{c}\text { Zaman } \\
\text { Kullanımı }\end{array}$} & Çalışma & $50 \%$ \\
\hline & Pozitif duygular & $17 \%$ & & \multirow{3}{*}{ Uyku } & \multirow{3}{*}{$50 \%$} \\
\hline & Negatif duygular & $17 \%$ & & & \\
\hline & Maneviyat & $33 \%$ & & & \\
\hline \multirow{4}{*}{ Sağlık } & Sağlığa ilişkin bildirim & $10 \%$ & \multirow{4}{*}{ İyi Yönetişim } & Politik katılım & $40 \%$ \\
\hline & Sağlıklı günler & $30 \%$ & & Hizmetler & $40 \%$ \\
\hline & Engelli olma durumu & $30 \%$ & & $\begin{array}{l}\text { Hükümetin } \\
\text { performans1 }\end{array}$ & $10 \%$ \\
\hline & Ak1l sağllğg & $30 \%$ & & Temel haklar & $10 \%$ \\
\hline \multirow[t]{4}{*}{ Eğitim } & Okuryazarlık & $30 \%$ & \multirow{4}{*}{$\begin{array}{l}\text { Toplumsal } \\
\text { Canlılık }\end{array}$} & $\begin{array}{c}\text { Bağış (Zaman } \\
\text { ve Para) }\end{array}$ & $30 \%$ \\
\hline & Okullaşma & $30 \%$ & & Güvenlik & $30 \%$ \\
\hline & Bilgi & $20 \%$ & & $\begin{array}{l}\text { Toplum } \\
\text { ilişkileri }\end{array}$ & $20 \%$ \\
\hline & Değer & $20 \%$ & & Aile & $20 \%$ \\
\hline \multirow{7}{*}{$\begin{array}{c}\text { Kültürel Çeşitlilik } \\
\text { ve } \\
\text { Esneklik }\end{array}$} & 13 güzel sanat ve el sanatları & $30 \%$ & \multirow{4}{*}{$\begin{array}{c}\text { Ekolojik } \\
\text { Çeşitlilik ve } \\
\text { Esneklik }\end{array}$} & $\begin{array}{l}\text { Vahşi yaşama } \\
\text { verilen zarar }\end{array}$ & $40 \%$ \\
\hline & Kültürel katılım & $30 \%$ & & $\begin{array}{c}\text { Kentsel } \\
\text { sorunlar }\end{array}$ & $40 \%$ \\
\hline & Ana dilde konuşma & $20 \%$ & & $\begin{array}{c}\text { Çevresel } \\
\text { sorumluluk }\end{array}$ & $10 \%$ \\
\hline & Görgü kuralları & $20 \%$ & & $\begin{array}{c}\text { Ekolojik } \\
\text { sorunlar }\end{array}$ & $10 \%$ \\
\hline & & & \multirow[t]{3}{*}{$\begin{array}{c}\text { Yaşam } \\
\text { Standardı }\end{array}$} & $\begin{array}{c}\text { Kişi başına } \\
\text { gelir }\end{array}$ & $33 \%$ \\
\hline & & & & Varlıklar & $33 \%$ \\
\hline & & & & $\begin{array}{c}\text { Konut } \\
\text { (Barınma) }\end{array}$ & $33 \%$ \\
\hline
\end{tabular}

Kaynak: Ura vd., 2015: 26 
Bu 33 gösterge arasında insanların en yeterli olduğu gösterge, \% 99 ile eğitim alanında yer alan değerdir. Değer göstergesini, kültürel çeşitlilik ve esneklik alanında yer alan ana dilde konuşma \% 92 ve toplumsal canlılık alanında yer alan güvenlik \%92 oranıla takip etmektedir (Ura vd, 2015: 30).

\section{Şekil 2: Gayrisafi Milli Mutluluk Endeksinde Her Bir Alanın Katkısı}

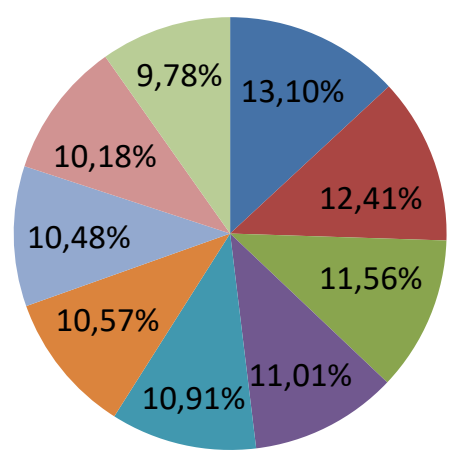

Sağlık
Ekolojik Çeşitlilik
Toplumsal Canlılık
Kültürel Çeşitlilik
Yaşam Standardı
Zaman Kullanımı
Psikolojik İyilik Hali
İyi Yönetişim

Kaynak: Ura vd, 2015: 30

Söz konusu dokuz alandan en yüksek ağırlı̆̆ bulunan gösterge, sağlık alanındadır. En düşük ağırlığı bulunan gösterge ise eğitim alanındadır (Ura vd, 2015: 30). Gayrisafi Milli Mutluluk endeksinde kullanılan dokuz alanın ağırlığı, görüldüğü üzere birbirine yakın dağılımlar göstermektedir.

Bhutan'da kullanılan Gayrisafi Milli Mutluluk endeksi, vatandaşların mutluluğunu ölçen bir endekstir. Söz konusu ölçüm; maneviyat, kültür ve toplum boyutları gibi diğer endeks çeşitlerinde bulunmayan bazı faktörleri içermektedir. Gayrisafi Milli Mutluluk, aslında Gayrisafi Yurtiçi Hasıla’ya iyi bir tamamlayıcı niteliğindedir ve vatandaşlarının mutluluğu üzerine daha fazla odaklanmak isteyen diğer ülkelerde uygulanabilir (Chen, 2015: 72).

Tablo 6. Gayrisafi Milli Mutluluk Endeksinin Kategorileri - Kişi Sayısı ve Yeterlilik

\begin{tabular}{|c|c|c|c|c|c|}
\hline \multicolumn{2}{|c|}{} & Gayrisafi Milli Mutluluk Endeksi & \multicolumn{2}{c|}{$\begin{array}{c}\text { Gayrisafi Milli Mutluluk } \\
\text { Endeksi 2010 }\end{array}$} \\
\hline $\begin{array}{c}\text { Mutluluk } \\
\text { Derecesi }\end{array}$ & $\begin{array}{c}\text { Grupların } \\
\text { tanımı }\end{array}$ & $\begin{array}{c}\text { Nüfusun } \\
\text { Yüzdesi }\end{array}$ & $\begin{array}{c}\text { Etki alanı } \\
\text { içinde her bir } \\
\text { bireyin } \\
\text { ortalama } \\
\text { yeterliliği }\end{array}$ & $\begin{array}{c}\text { Nüfusun } \\
\text { Yüzdesi } \\
\text { içinde her } \\
\text { bir bireyin } \\
\text { ortalama } \\
\text { yeterliliği }\end{array}$ \\
\hline $\begin{array}{c}\text { Son derece } \\
\text { mutlu }\end{array}$ & $77 \%-100 \%$ & $8,42 \%$ & $80,95 \%$ & $8,3 \%$ & $81,5 \%$ \\
\hline $\begin{array}{c}\text { Büyük ölçüde } \\
\text { mutlu }\end{array}$ & $66 \%-\% 76$ & $34,97 \%$ & $70,80 \%$ & $32,6 \%$ & $70,7 \%$ \\
\hline Az mutlu & $50 \%-65 \%$ & $47,87 \%$ & $59,11 \%$ & $48,7 \%$ & $59,1 \%$ \\
\hline Mutsuz & $0-49 \%$ & $8,75 \%$ & $45,18 \%$ & $10,4 \%$ & $44,7 \%$ \\
\hline
\end{tabular}

Kaynak: Ura vd, 2015: 29, 48 
Tablo 6'daki analizde, her bir grup mutluluk derecelerine göre kategorize edilmiştir. Böylece 2015 Gayrisafi Milli Mutluluk endeksi sonuçlarına göre, her bir grubun ait olduğu nüfusun yüzdesine ilişkin bilgiler elde edilmiştir (Ura vd, 2015: 29). Bu bağlamda son derece mutlu olarak tanımlanan \%77-\%100 aralığına ait grup, 2010 yılında nüfusun \%8,3’ünü oluştururken 2015 yılında ise nüfusun \%8,42'sini oluşturmuştur. Dolayısıyla Gayrisafi Milli Mutluluk Endeksinin 2015 sonuçları ile 2010 sonuçları, birbirine yakın oranlara sahiptir.

Tablo 7. Bhutan Krallığı’nda 2010 Yılından 2015 Yılına Kadar Gayri Safi Milli Mutluluk Göstergelerinde Oluşan Önemli Değişiklikler

\begin{tabular}{|c|c|c|}
\hline Önemli Ölçüde İyileşme & Değişim Gerçekleşmeyen & Önemli Ölçüde Kötüleşme \\
\hline Göstergeler & Göstergeler & Göstergeler \\
\hline Hizmetler & Kentleşme sorunlar & Yaşam memnuniyeti \\
\hline Ekolojik sorunlar & Değerler & Aile \\
\hline Sağlıklı günler & Bilgi & Bağış (Zaman ve Para) \\
\hline Kültürel katılım & Sanatsal beceriler & Güvenlik \\
\hline & & Çevresel sorumluluk \\
\hline Konut & Anadilde konuşma & Pozitif duygular \\
\hline Vahşi hayata verilen zarar & Çalışma & Politik katılım \\
\hline Uyku & Okullaşma & Negatif duygular \\
\hline Varlıklar & Engelli olma durumu & \\
\hline Kişi başına düşen gelir & & Temel haklar \\
\hline Okuryazarlık & & Maneviyat \\
\hline \multirow[t]{4}{*}{ Ak1l sağlığ 1} & & Görgü kuralları \\
\hline & & Toplum ilişkileri \\
\hline & & Hükümet performans1 \\
\hline & & Sağlığa ilişkin bildirim \\
\hline
\end{tabular}

Kaynak: Ura vd, 2015: 49

Göstergelerdeki en büyük gelişme hizmetler, ekolojik sorunlar, sağl1klı günler, kültürel katılım ve konutta (barınma) gerçekleşmiştir. Bu 5 gösterge, 2010 yılı ile karşılaştırıldığında \% 10'un üzerinde artış göstermiştir. Buna karşın Bhutan Krallığ halkında birçok gösterge, Tablo 7'de görüldüğü üzere kötüye gitmiştir (Ura vd, 2015: 49).

Gayrisafi Milli Mutluluk endeksini diğer hesaplamalardan ayırt edici kılan bazı özellikleri bulunmaktadır. Birincisi, Gayrisafi Milli Mutluluk maneviyatı kapsayan psikolojik iyilik halini dikkate almakta ve manevi ihtiyaçların eksikliğini gideren bir materyale dayanmaktadır. GayriSafi Milli Mutluluğun, bireylerin hem fiziksel hem de ruhsal iyilik hallerine ilişkin bütüncül ihtiyaçlarını simgelediği ileri sürülmektedir. İkincisi, Gayrisafi Milli Mutluluk endeksi, insanların resim yapma ve dokumacılık gibi ustalık gerektiren yetenekleri elde etme derecesine göre kültür başlığı altında yaratıcılığı göz önüne almaktadır. Bireyin yaratıcı hayal gücü ve karmaşık teknikleri kullanarak sanat çalışmasını şekillendirmesi, hoş ve memnuniyet verici karşılanmaktadır. Refahın bu boyutu HDI (Human Development Index - İnsani Gelime Endeksi) ve BLI (Better Life Index - Daha İyi Yaşam Endeksi) gibi diğer endeksler tarafından ihmal edilmektedir. Üçüncüsü, Gayrisafi Milli Mutluluk insanların yaşamları için temel oluşturan toplum ile aile ilişkilerini kapsayan 
toplumsal canlılık ile ilgilenmektedir. Bhutan halkı aidiyet duygusu ile komşulara güvenmeyi, mutluluğun bir parçası olarak görmektedir (Chen, 2015: 69).

\section{Sonuç}

Gayrisafi milli mutluluk ilk defe 1972'de Bhutan Krallı̆̆ı'nda gündeme gelmiştir. Bu çerçevede gayrisafi milli mutluluk kavramı, mutluluk ekonomisi literatüründe kendine önemli bir yer edinmiştir. Gayrisafi milli mutluluk; psikolojik iyilik hali, sağlık, zaman kullanımı, eğitim, kültürel çeşitlilik ve esneklik, iyi yönetişim, topluluğun canlılık, ekolojik çeşitlilik ve esneklik ile yaşam standardı olmak üzere dokuz alanda geliştirilen 33 göstergeden oluşmaktadır. Gayrisafi Milli Mutluluk insanların yaşamları için temel oluşturan toplum ile aile ilişkilerini kapsayan toplumsal canlılık ile ilgilenmektedir. Bhutan halkı aidiyet duygusu ile komşulara güvenmeyi mutluluğun bir parçası olarak görmektedir.

Gayrisafi Milli Mutluluk endeksini diğer hesaplamalardan ayırt edici kılan bazı özellikleri bulunmaktadır. Öncelikle, Gayrisafi Milli Mutluluk, maneviyatı kapsayan psikolojik iyilik halini dikkate almakta ve manevi ihtiyaçların eksikliğini gideren bir materyale dayanmaktadır. Gayri Safi Milli Mutluluğun bireylerin hem fiziksel hem de ruhsal iyilik hallerine ilişkin bütüncül ihtiyaçlarını simgelediğini ileri sürülmektedir. Gayrisafi Milli Mutluluk endeksi, insanların resim yapma ve dokumacılık gibi ustalık gerektiren yetenekleri elde etme derecesine göre kültür başlığı altında yaratıcılığı da göz önüne almaktadır. Bireyin yaratıcı hayal gücü ve karmaşık teknikleri kullanarak sanat çalışmasını şekillendirmesi, hoş ve memnuniyet verici faaliyetler olarak görülerek Gayrisafi Milli Mutluluk endeksinde yer verilmiştir.

Mutluluk hesaplamalarındaki farklılıklar, araştırmalardaki farklı göstergeler ve göstergelerin sahip olduğu farklı ağırlıklandırmalardan kaynaklanmaktadır. Bu bağlamda mutlak bir mutluluk tanımı olmadığı gibi evrensel bir mutluluk modeli de söz konusu değildir. Buna karşın, Gayri Safi Milli Mutluluk, Gayri Safi Yurtiçi Hasıla’ya iyi bir tamamlayıcı niteliğindedir ve vatandaşlarının mutluluğu üzerine daha fazla odaklanmak isteyen diğer ülkelerde uygulanabilir özellikler taşımaktadır. Gayrisafi Milli Mutluluk, Gayrisafi Yurtiçi Hasıla'nın içermediği piyasa dışı katkıları da kapsamaktadır. Gayrisafi Milli Mutluluk, Gayrisafi Yurt İçi Hasıla'ya tam bir ikame olmasa da tamamlayıcısı olarak kabul görmektedir. Geleneksel kalkınma modellerinden farklı olarak Gayrisafi Milli Mutluluk, çevresel değerleri de bünyesinde barındırmaktadır. 


\section{KAYNAKÇA}

BLANCHFLOWER, D.G. ve OSWALD, A.J. (2005). Happiness and the Human Development Index: The Paradox of Australia, NBER Working Paper Series.

CHEN, H. (2015). An Analysis of Bhutan's Gross National Happiness. Seven Pillars Institute Moral Cents, 4 (2), 66-74.

CİNGİ, S. (2011), Bencillik Ekonomisinin İflas1 - İktisat, İnsan ve Mutluluk Üzerine Bir Deneme, Sobil Yayıncılık, Ankara

DEMIR, Ö. (2013). Din Ekonomisi - İnanç, Zenginlik ve Mutluluk. Sentez Yaylncıllk, Bursa.

DUMLUDAĞ, D. (2014). Fayda, Mutluluk ve Refah. Kalkınmada Yeni Yaklaşımlar. A.F. Aysan \& D. Dumludağ, İmge Kitabevi, 365-387.

EASTERLIN, R. (1974). Does Economic Growth Improve the Human Lot? Some Empirical Evidence. published in Nations and Households in Economic Growth, ed.P. David and M. Reder. New York: Academic Press.

EASTERLIN, R. (2001). Income and Happiness: Toward a Unified Theory. Economic Journal, 111, 465-484.

GÖKDEMİR, Ö. ve VEENHOVEN, R. (2014). Kalkınmaya Farklı Bir Bakış: İyi Oluş. Kalkınmada Yeni Yaklaşımlar, ed. A.F. Aysan \& D. Dumludağ, İmge Kitabevi, 337 $-364$.

HELLIWELL, J., LAYARD, R. Ve SACHS, J. (2017). World Happiness Report. The Earth Institute Columbia University.

JEFFREY, K. (2016). This is The Most Efficient Economy in The World. New Economics Foundation,

http://neweconomics.org/2016/07/this-is-the-most-efficient-economy-in-theworld/?sf action=get results\& sft latest=articles\&sf paged=11 [E.T. 17.06.2017]

KAHNEMAN, D. ve DEATON, A. (2010). High Income Improves Evaluation of Life But Not Emotional Well-being. Proceedings of the National Academy of Sciences in the United States of America, 107, 16489-16493.

MACKERRON, G. (2012). Happiness Economics from 35000 Feet. Journal of Economic Surveys, 26 (4), 705-735.

MILL, J.S. (2017). Faydacılık. Çev: Selin Aktuyun, Alfa Yayıncılık, İstanbul

NEW ECONOMIC FOUNDATION (2016). The Happy Planet Index. http://happyplanetindex.org/ [E.T. 23.06.2017]

STEVENSON, B. ve WOLFERS, J. (2008). Economic Growth and Subjective Well-Being: Reassessing the Easterlin Paradox. IZA Discussion Paper, No: 3654.

ŞEKER, F. ve ÇETIN, M, (2012). Faydacı Refah Ekonomisi: Amartya Sen'in Eleştirisi. SÜ IIIBF Sosyal ve Ekonomik Araştırmalar Dergisi, (24), 277-304.

ŞEKER, M. (2016). Mutluluk Ekonomisi - Kamu Ekonomisi Açısından Bir Analiz. Türkmen Kitabevi, İstanbul 
ŞİMŞİR, N.C. (2013). Türkiye'de Mutluluk Ekonomisinin Belirleyicilerinin Ekonometrik Analizi. Finans Politik \& Ekonomik Yorumlar, 50 (579), 7-22.

TÜRKÇE SÖZLÜK (2005), Türk Dil Kurumu Yayınları, Ankara

TIAN, G. ve YANG, L. (2006). A Formal Economic Theory for Happiness Studies: A Solution to the Happiness-Income Puzzle. http://people.tamu.edu/ gtian/happy2.pdf, [E.T. 04.06.2017]

TÜIK $\quad$ Yaşam Memnuniyeti Araştırması http://www.tuik.gov.tr/PreHaberBultenleri.do?id=24641, [E.T. 25.07.2017]

URA, K., ALKIRE, S., ZANGMO, T. ve WANGDI, K. (2015). Provisional Findings of 2015 Gross National Happiness Survey. Centre for Bhutan Studies \& GNH Research

WHITE, A. (2007). A Global Projection of Subjective Well-being: A Challenge to Positive Psychology?. Psychtalk, 56, 17-20.

WORLD VALUES SURVEY (2015), "World Values Online Data Analysis", http://www.worldvaluessurvey.org/WVSDocumentationWV6.jsp, [E.T. 18.06.2017]

VEENHOVEN, R. (2004). Happy Life Years: A Measure of Gross National Happiness. K. Ura \& K. Galay (Ed.), in Gross National Happiness and Development, 287-318.

VEENHOVEN, R. (2015). Average Happiness in 158 nations 2005-2014. World Database of Happiness.

http://worlddatabaseofhappiness.eur.nl/hap nat/findingreports/RankReport Average Happiness.php [E.T. 02.07.2017]

VEENHOVEN, R. ve DUMLUDAĞ, D. (2015). Iktisat ve Mutluluk: Bugün Daha Mutlu muyuz?. Chapter 11 in: Dumladağ, D., Gökdemir, O., Neyse, L. \& Ruben, E. (Ed.), İktisatta Davranışsal Yaklaşımlar (Behavioral Approaches In Economics), Imge Kitabevi, Ankara Turkey, 201-230. 